\title{
ULTRASONOGRAPHIC CHARACTERISTICS OF MARES' OVARIES IN THE DIFFERENT SEASONS IN EGYPT
}

\author{
EMAD M. M. ABD EL-RAZEK ${ }^{1}$ and HAMADA D. H. MAHBOUB ${ }^{2}$ \\ ${ }^{1}$ Dept. of Theriogenology, Faculty of Veterinary Medicine, University of Sadat City, Sadat city, Egypt \\ ${ }^{2}$ Dept. of Husbandry, Faculty of Veterinary Medicine, University of Sadat City, Sadat city, Egypt
}

Received: 5 May 2019; Accepted: 30 July 2019

\begin{abstract}
The present study was conducted to detect the ovarian activities of mares using ultrasonography in relation to the different seasons of the year under Egyptian environmental conditions. This study was carried out on 465 clinically healthy and non-lactating mares. The animals were cyclic and showed signs of estrus regularly. The experimental period was extended from January 2014 to December 2016. All mares were examined with ultrasonography for determination of the reproductive status of each mare specially the degree of activity of the two ovaries monthly. The degree of ovarian activity was either inactive or active according to size of follicles. The results were illustrated that the highest ovarian activity of mares was extended from March till July. On contrary, during November, December and January mares were had higher percentages of smooth ovaries than other months throughout the year. In relation to the season, the highest ovarian activity was reached late spring and early summer while, the least ovarian activity was in late autumn and early winter with minimal ovarian activity in winter season. Ovarian activity in mare was found all over the year with the highest ovarian activity in spring and summer and the lowest ovarian activity in autumn and winter. It was concluded that under Egyptian conditions, most mares have the ability to show continue cycling activity throughout the year, however, photoperiod play an important role in the intensity of ovarian activity and reproductive cycle.
\end{abstract}

Key words: Ultrasound, ovarian activity, mare, season

\section{INTRODUCTION}

The mare is seasonally polyestrus, with estrus cycles beginning in mid to late winter and continue throughout the early fall (Colquhoun et al., 1987; Ginther, 1992 and Williams et al., 2012). The main objective of the equine breeder is to get maximum number of foals from breeding mare in its lifetime during the limited breeding season efficiently and this can be achieved if one foal is obtained every year. Mares exhibit estrus behavior during the anovulatory period and this is probably due to the release of estrogenic steroids from the adrenal cortex (Sharon and Crowell-Davis, 2007). So that, some mares would show behavioral signs of estrus, throughout the year, that may be accompanied by ovulation (Hafez and Hafez, 2000; Nie, 2007). The endocrinology of the estrus cycle involves a balance between hormones produced by pineal gland, hypothalamus, pituitary gland, ovaries and endometrium (Salué and Gardon, 2013). In addition, there are many factors that influence estrus cycle in mares such as season, age,

Corresponding author: Dr. Hamada D. H. Mahboub E-mail address: hamada11eg@yahoo.co.uk

Present address: Dept. of Husbandry, Faculty of Veterinary Medicine, University of Sadat City, Sadat city, Egypt breed and pregnancy. During dark hours, melatonin was secreted by pineal gland. In spring and summer, there is less melatonin secretion, and the hypothalamus secretes gonadotropin-releasing hormone $(\mathrm{GnRH})$ to induce gonadotropins secretion in the anterior pituitary and stimulates the ovulatory function (Zimri Cortés-Vidauri et al., 2018). The photoperiod is the most important external factor that influences the seasonality in mares (Parvizi, 2000). Mare's ovaries with follicles less than $20 \mathrm{~mm}$ in diameter are inactive (Ginther, 1992; Nequin et al., 2000; King et al., 2002 and Nunes et al., 2005). The usage of trans-rectal ultrasonography to evaluate the dynamic changes of the equine ovaries has been a major device in improvement of equine reproduction (Squires et al., 1988). Now trans-rectal ultrasonography is widely used for several purposes including detection of follicular development, size of pre-ovulatory follicle, ovulation and uterine edema for timely breeding. Moreover, early pregnancy, twins and embryonic development are detected after mating also by ultrasonography (Gastal et al., 1997 and Arbal et al., 2015). The size of a follicle is an important factor for growth as well as the selection process of the dominant follicle and is used as a guiding tool to predict ovarian activity in the mare (Gastal et al., 1997). Ultrasonography provided the opportunity to visualize the mare's ovaries to detect 
the diameter of diverse follicles and to predict the day of ovulation according to follicles size, thus the state of ovaries in mares (Benallou and Meliani, 2011). The present study was conducted to detect the ovarian activities of mare using ultrasonography in relation to the different seasons of the year.

\section{MATERIALS AND METHODS}

\section{Animals and Management}

All animal-handling and examination procedures were according to the regulations of Institutional Animal Care and Use Committee (IACUC), Faculty of Veterinary Medicine, University of Sadat City.

This study was carried out on 465 clinically healthy, non-lactating mares, aging 3-15 years old and weighing 350-550 kg. The animals were cyclic and showed signs of estrus regularly. The experimental period was extended from January 2014 to December 2016. All the mares were reared in different farms in Al-bohira Governorate, which is located at $30.61^{\circ} \mathrm{N}$ $30.43^{\circ} \mathrm{E}, 7$ meters above sea level.

The animals were fed green fodder, hay and a commercial concentrate as well as they had free access to mineralized salt and drinking water. Animals were kept under natural light in an open shelter and outdoor paddock during daytime and housed at night.

\section{Ultrasonic Examinations}

Ovaries of each mare were monitored trans-rectally once with a portable ultrasonic diagnostic system [Sonoscape Co. Ltd., China] provided with a $5 \mathrm{MHz}$ trans-rectal linear transducer. All mares were examined with ultrasonography for determination of the reproductive status of each mare specially the degree of activity of the two ovaries in relation to the time of the year. The degree of ovarian activity was either inactive or active according to size of follicles. When the two ovaries are small in size and hold small follicles less than $20 \mathrm{~mm}$ in diameter with no corpora luteum (CL), this case is inactive (Image, 1). While mare with active ovaries were contain number of follicles more than $20 \mathrm{~mm}$ in diameter with or without carry mature CL (Image, 2 \& 3) (Ginther, 1992; Nequin et al., 2000; King et al., 2002 and Nunes et al., 2005).

\section{Statistical Analysis.}

Collected data were statistically analysed using SAS version 8.0 (SAS, 2001). All data were compared using two-way ANOVA test and expressed as the Means \pm S.E.

\section{RESULTS}

In the present study, the highest ovarian activity of mares was extended from March till July. On contrary, during November, December and January, mares had higher percentages of smooth ovaries than other months throughout the year as shown in Table (1). Moreover, percentage of ovarian activities that were detected by ultrasonography in mares was higher in spring and summer than winter and autumn (Table 2). In addition, mares that had the highest percent of large follicles were recorded during spring while the highest percent of small follicles were observed in mares with inactive ovaries during winter, where there were almost no large follicles (Table 2).

As shown in Figure (1), the highest proportion of corpus luteum (CL) was detected in mares during five months extended from April to August (25.5, 25.4, $21.5,39.8$, and $36 \%$, respectively). The percent of CL was gradually reduced from August till December in most cases. Furthermore, in relation to seasons, the most CL in mares was recorded in summer $(32.4 \%)$ in comparison with spring, winter and autumn $(19.8 \%, 8.3 \%$, and $13.9 \%$ respectively) followed by spring then autumn $(P<0.05)$ as shown in Figure (2).

Table 1: Percentage of ovarian state (smooth or active) that was detected by ultrasonography in mares during different months (Means \pm SE).

\begin{tabular}{ccc}
\hline \multirow{2}{*}{ Months } & \multicolumn{2}{c}{ Ovarian state } \\
\cline { 2 - 3 } & Smooth & Active \\
\hline January & $79.57 \pm 1.41^{\mathrm{a}}$ & $14.07 \pm 2.91^{\mathrm{cd}}$ \\
\hline February & $49.27 \pm 4.41^{\mathrm{c}}$ & $37.07 \pm 3.14^{\mathrm{ab}}$ \\
\hline March & $50.97 \pm 6.54^{\mathrm{bc}}$ & $40.63 \pm 4.42^{\mathrm{a}}$ \\
\hline April & $43.17 \pm 5.56^{\mathrm{c}}$ & $31.33 \pm 9.57^{\mathrm{abcd}}$ \\
\hline May & $31.03 \pm 6.02^{\mathrm{d}}$ & $43.57 \pm 8.87^{\mathrm{a}}$ \\
\hline June & $31.93 \pm 2.32^{\mathrm{d}}$ & $46.53 \pm 9.01^{\mathrm{a}}$ \\
\hline July & $19.43 \pm 6.33^{\mathrm{e}}$ & $40.73 \pm 5.86^{\mathrm{a}}$ \\
\hline August & $44.7 \pm 1.7^{\mathrm{c}}$ & $19.33 \pm 6.12^{\mathrm{bcd}}$ \\
\hline September & $58.33 \pm 13.27^{\mathrm{b}}$ & $33.33 \pm 12.18^{\mathrm{abc}}$ \\
\hline October & $27.77 \pm 9.29^{\mathrm{d}}$ & $20.37 \pm 6.52^{\text {bcd }}$ \\
\hline November & $72.77 \pm 8.62^{\mathrm{a}}$ & $12.23 \pm 3.92^{\mathrm{d}}$ \\
\hline December & $77.97 \pm 4.87^{\mathrm{a}}$ & $17.07 \pm 3.29^{\mathrm{bcd}}$
\end{tabular}

\footnotetext{
${ }^{\mathrm{a}-\mathrm{e}}$ means of different letters within the same column were significant at $P<0.05$
} 
Table 2: Percentage of ovarian state (smooth or active) that was detected by ultrasonography in mares in relation to seasons. (Means $\pm \mathrm{SE}$ ).

\begin{tabular}{ccc}
\hline \multirow{2}{*}{ Seasons } & \multicolumn{2}{c}{ Ovarian state } \\
\cline { 2 - 3 } & Smooth & Active \\
\hline Winter & $68.93 \pm 3.98^{\mathrm{a}}$ & $22.73 \pm 3.51^{\mathrm{b}}$ \\
\hline Spring & $41.72 \pm 3.84^{\mathrm{c}}$ & $38.51 \pm 4.49^{\mathrm{a}}$ \\
\hline Summer & $32.02 \pm 3.32^{\mathrm{d}}$ & $35.53 \pm 4.8^{\mathrm{a}}$ \\
\hline Autumn & $52.96 \pm 7.33^{\mathrm{b}}$ & $21.98 \pm 4.96^{\mathrm{b}}$ \\
\hline
\end{tabular}

${ }^{\mathrm{a}-\mathrm{c}}$ means of different letters within the same column were significant at $P<0.05$

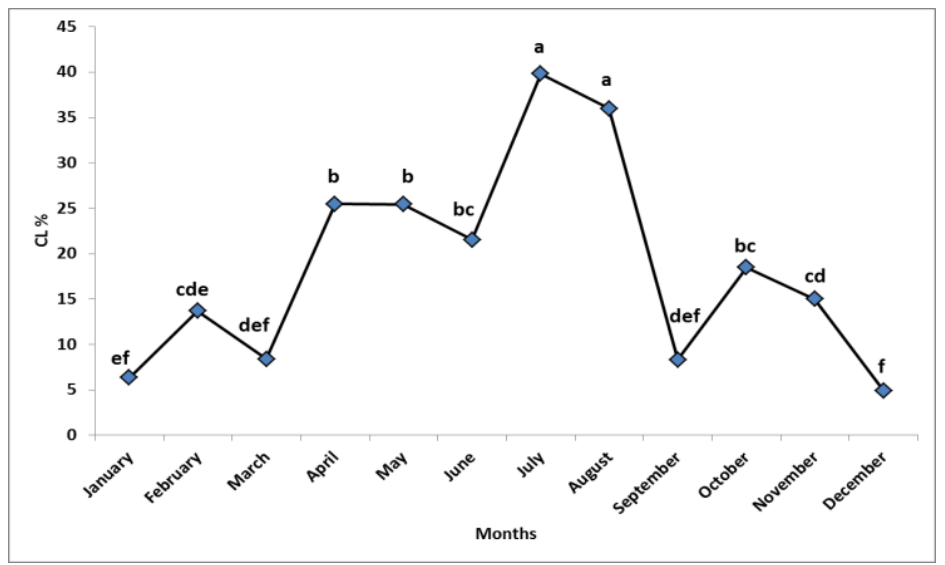

Figure 1: Percentage of corpora lutea (CL) that was detected by ultrasonography in mares during different months $\left({ }^{\mathrm{a}-\mathrm{c}}\right.$ means of different letters within the same column were significant at $P<0.05$ ).

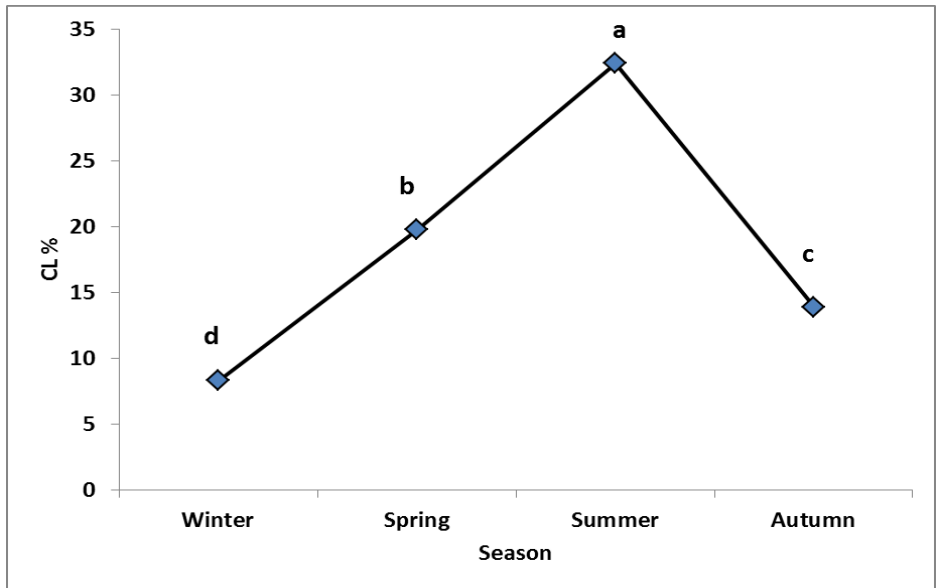

Figure 2: Percentage of corpora lutea (CL) that was detected by ultrasonography in mares in relation to seasons $\left({ }^{\mathrm{a}-\mathrm{c}}\right.$ means of different letters within the same column were significant at $P<0.05$ ).
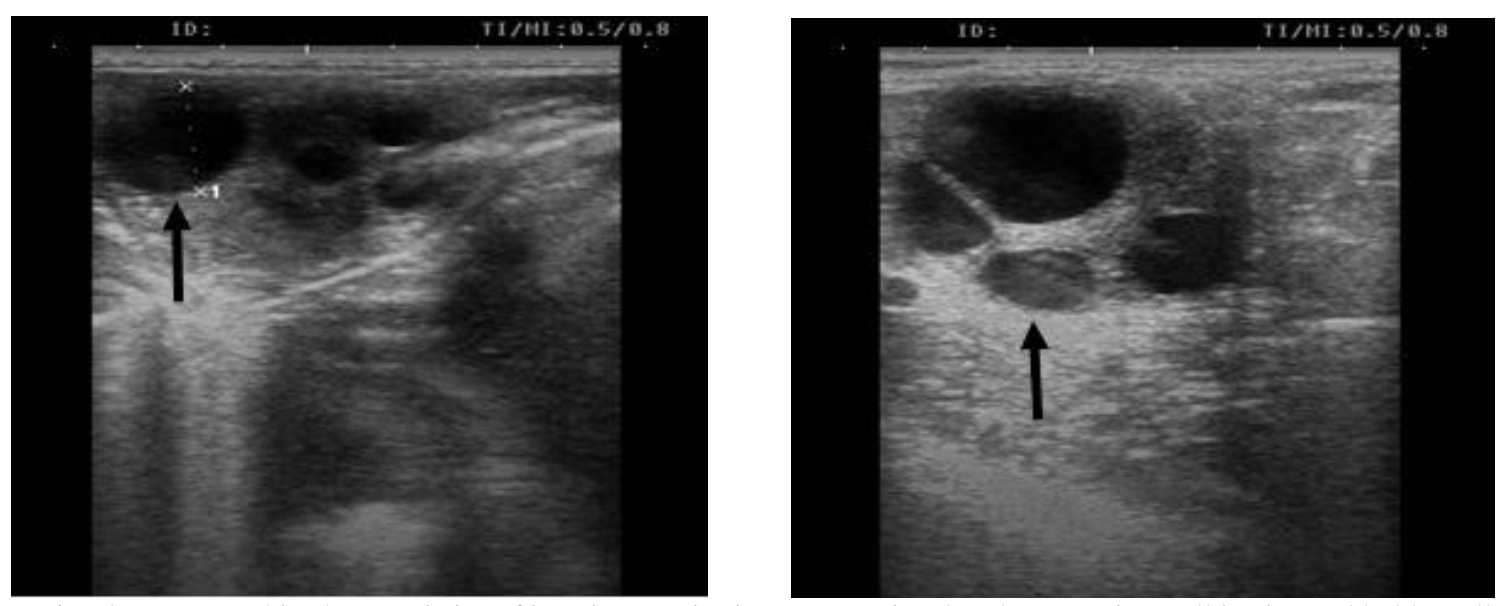

Image 1: Ultrasonographic characteristics of inactive ovaries in mare. Notice that the ovary is small in size and hold smal follicles of less than $20 \mathrm{~mm}$ in diameter (arrows). 

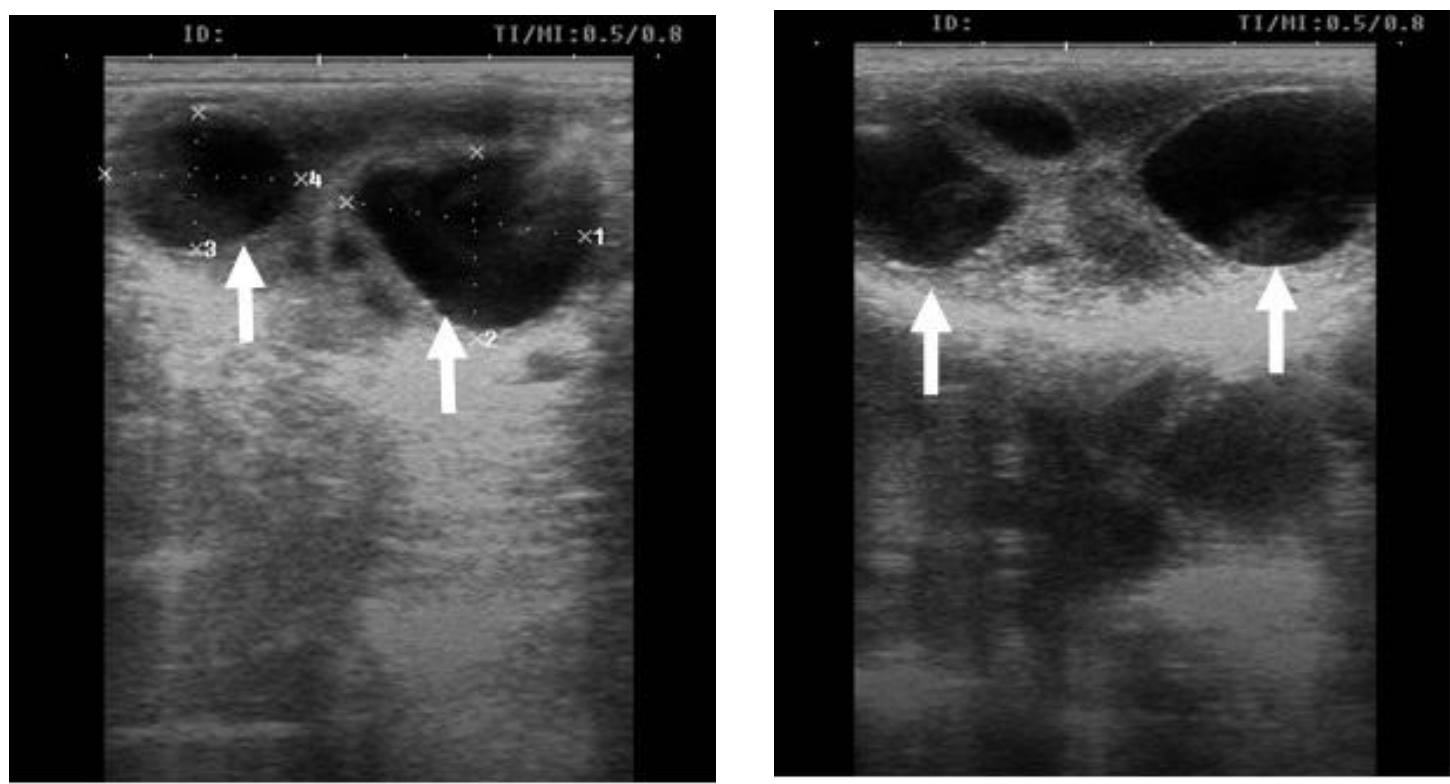

Image 2: Ultrasonographic characteristics of mare's ovaries in the transition period. Notice that the size of the ovaries was appeared slightly enlarged with multiple follicles (arrows) and some of these follicles are large in size (more than $20 \mathrm{~mm}$ in diameter).
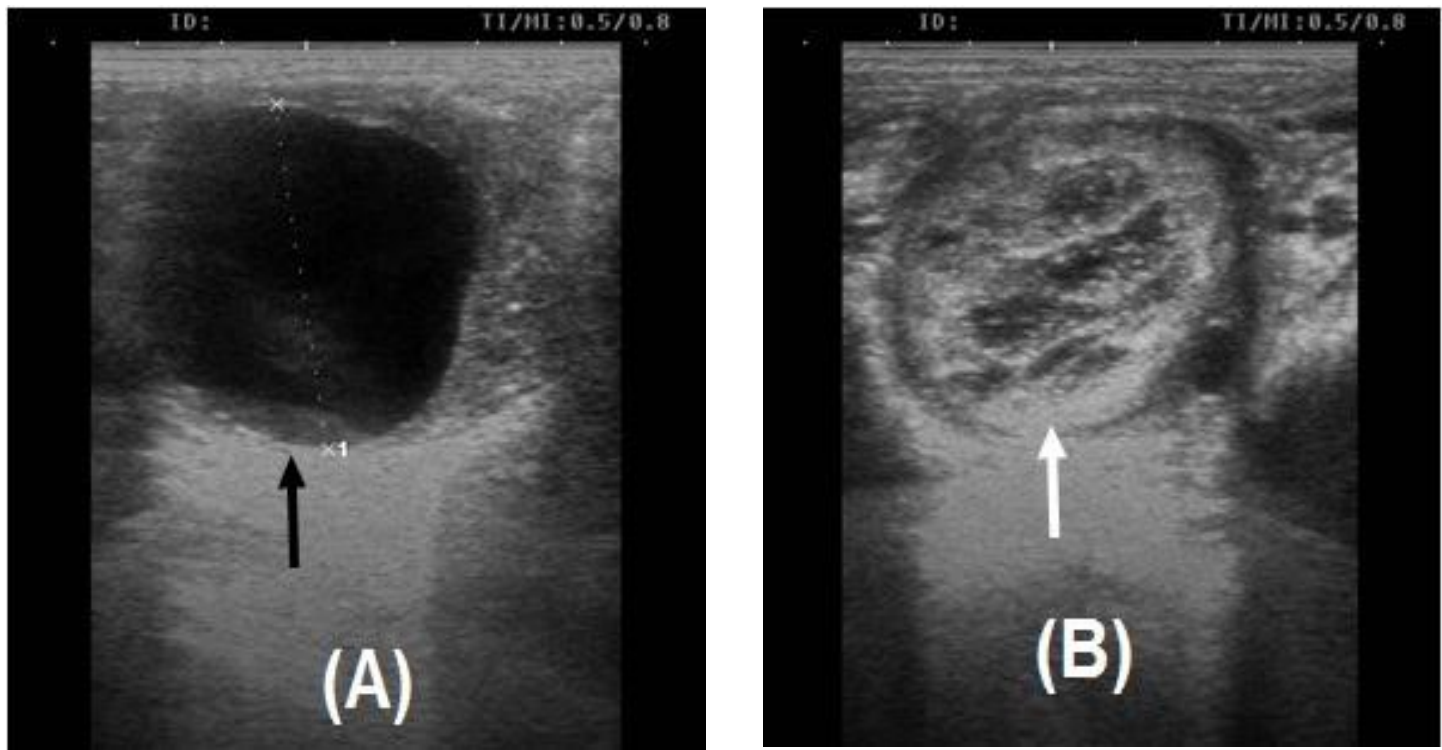

Image 3: Ultrasonographic characteristics of active ovaries in mare. Notice that: (A) the ovary is large in size and hold large follicle (black arrow) of more than $35 \mathrm{~mm}$ in diameter and loss its circular shape to appear spheroid (pear shape), (B) corpus luteum (white arrow).

\section{DISCUSSION}

The main goal of the equine breeder is to get a maximum number of foals from breeding mare in its lifetime through a limited breeding season. During heat, ovary of the mare had one or more ovarian follicle (s) that would become the dominant follicle in comparison to size of other follicles. Stimulation of estrous behavior, relaxation of cervical muscles, edema formation within the uterine lining, and secretion of luteinizing hormone (LH) from the pituitary were under effect of estrogens that produced by the dominant follicle. In most cases, LH will promote the final maturation of the dominant follicle and induce ovulation (Sharon and Crowell-Davis, 2007).

In the present study, through the period from March till July, mares had the highest ovarian activity. Then, during November, December and January, mares showed higher percentages of smooth ovaries than other months throughout the year. According to season, spring and summer were the main seasons in which the percentage of ovarian activities in mares 
was the highest. However, in winter and autumn, there were small percentages of large follicles and corpora lutea recorded. In former, Palmer and Guillaume, (1992); Nagy et al. (2000) said that mare is a seasonally polyestrous species that normally ovulates during the months of spring and summer. Also, photoperiod is the most important regulator of this seasonal reproductive pattern. The short day length characteristic of fall and winter in regions located at high latitudes causes an increase in the daily duration of melatonin secretion, and this leads to decreased secretion of GnRH and the cessation of ovulatory activity (Palmer and Guillaume, 1992; Nagy et al., 2000 and Zimri Cortés-Vidauri et al., 2018).

Limited information is available about the seasonality of ovarian activity of the mare at latitudes far to the Equator. In Egypt, the annual distribution of estrus in mares located in Al-behira Governorate $\left(30.61^{\circ} \mathrm{N}\right.$ $30.43^{\circ} \mathrm{E}$ ) was a moderate incidence of estrus during February $(P<0.05)$. In addition, from March the incidence of estrus start to increase and reach the highest incidence from April to July as the mean of animals with large follicles was numerically high compared to animals that showed smooth ovaries. However, no studies have been carried out at the latitude of Al-behira Governorate in which the ovarian activity of mares has been followed using progesterone determinations and ultrasound observations during the months with reduced ovulatory activity. Thus, whether all mares go through a period of ovarian inactivity is unknown but this might be due to the length of photoperiod in this period of the year and secretion of melatonin as reported by Nagy et al. (2000) and Zimri CortésVidauri et al. (2018). On the same direction, the ovarian state of mares during August, Septamber, October, November and December was significantly smooth and was still numerically high during January and February which appeared in accordance with that reported by Palmer and Guillaume, 1992; Nagy et al., 2000 and Zimri Cortés-Vidauri et al., 2018).

In addition, mares that had the largest follicles were recorded during spring in comparison with mares with inactive ovaries that were significantly high in winter, when there were few large follicles. Ovarian inactivity was significantly reduced from late winter till early autumn in mares that showed smooth ovaries. These results were agreed with Saltiel et al. (1982) who suggested that a reduction in ovarian activity in mares was occurred during the winter.

The ovulatory period of the mare in northern countries was reported to occur during the months of spring and summer; however, little information is available regarding reproductive seasonality in regions close to the equator (Boeta et al., 2006) but the present study was used ultrasonographic evaluations for direct assessment of the changes in ovarian activity in mares located at $30.61^{\circ} \mathrm{N}$, under Egyptian condition. It was evident that, although there was a reduction in ovarian activity between November and February, more than $20 \%$ of the mares were continued ovulating throughout this period. This proportion of mares with continuous ovarian activity is in complete agreement with that reported at higher latitudes Koskinen et al. (1996) in a study made in Finland $\left(61^{\circ} \mathrm{N}\right)$ found that $22 \%$ of mares had cyclic secretion of progesterone during winter.

The highest proportion of corpus luteum (CL) was detected in mares during five months extended from April to August. The percent of CL was gradually reduced from August till December in most cases but still recorded. Furthermore, in relation to seasons, the most CL in mares was recorded in summer in comparison with spring, winter and autumn. Inactivity periods of the ovaries, this might be attributed to maintain progesterone concentrations below $1 \mathrm{ng} / \mathrm{mL}$ in most mares, and thus they did not show estrus signs, and have ovaries that are small and smooth, with follicles smaller than $20 \mathrm{~mm}$ in diameter (Ginther, 1990).

As shown in Figure 1, the mares had an ultrasonographically detectable CL between $5 \%$ and $40 \%$ of the times they were recorded, regardless of the month. The minimal proportion of observations in which a CL was detected during the months of January and December (5\%) and the highest proportion of observations in which a CL was detected during July (40\%) which appeared in complete agreement with Saltiel et al. (1982) who studied the ovaries of mares killed at slaughterhouse that processed animals of different breeds and ages that arrived from different Mexican states located between $15^{\circ}$ and $22^{\circ} \mathrm{N}$. They found that from November to February the proportion of animals with either corpora lutea or large follicles was significantly lower than from March to October. Those authors concluded that seasonal reproduction is present in mares kept at these latitudes. However, no studies have been carried out at the latitude of Al-behira Governorate in which the ovarian activity of mares has been followed using ultrasound observations during the months with reduced ovulatory activity. Thus, the interest findings that recorded in the current study were the ovarian states of mares in Al-behira Governorate located at $30.61^{\circ} \mathrm{N} 30.43^{\circ} \mathrm{E}$. Therefore, the ovarian activity period in mares that showed follicles of more than $20 \mathrm{~mm}$ and/ or CL was started in March and ended in August. Boeta et al. (2006) reported that, $62 \%$ of the mares had continuous ovulatory cycles from November through April (continuous mares), whereas $38 \%$ showed a period of ovulatory inactivity (seasonal mares). 


\section{CONCLUSION}

Trans-rectal ultrasonography is a good tool for determination of ovarian activity in mare. The highest ovarian activity in mare was at May, June and July and the lowest ovarian activity was during December and January. Late spring and early summer was the period of most ovarian activity while, late autumn and early winter was the period of ovarian in activity in mares. In contrast, there was a very low proportion $(20 \%)$ of mares were show ovarian activity during winter and autumn. In general, under Egyptian environmental conditions, most mares have the ability to show continue cycling activity throughout the year, however, photoperiod play an important role in the intensity of ovarian activity and reproductive cycle.

\section{REFERENCES}

Arbal, R.W.; Ingawale, M.V.; Deshmukh, S.G. and Hajare, S.W. (2015): Detection of preovulatory follicle size and early pregnancy by using ultrasonography in thoroughbred mares during foal heat. Indian J. of Animal Reproduction, 36 (1): 42-45.

Benallou, B. and Meliani, S. (2011): Ultrasonic measurement of follicle's diameter and bacteriological examination during foal heat in Arabian Mares. Middle-East Journal of Scientific Research, 8 (1): 46-51.

Boeta, M.; Porras, A.; Zarco, L.A. and AguirreHernández, R. (2006): Ovarian activity of the mare during winter and spring at latitude of $19^{\circ} 21^{\prime}$ north. J. of Equine Veterinary Science, 26: (2), 55-58

Colquhoun, K.M.; Echersall, P.D.; Renton, J.P. and Douglas, T.A. (1987): Control of breeding the mare. Equine Vet. J., 19, 138-142.

Gastal, E.L.; Gastal, M.O.; Bergfelt, D.R. and Ginther, O.J. (1997): Role of diameter differences among follicles in selection of a future dominant follicle in mares. Biol. Reprod., 57: 1320-1327

Ginther O.J. (1990): Folicullogenesis during the transitional period and early ovulatory season in mares. J. Reprod. Fertil., 90: 311-20.

Ginther, O.J. (1992): Reproductive Biology of the Mare. Basic and Applied Aspects, 2. Equiservices Publishing, Cross Plains, WI, USA.

Hafez, E.S.E. and Hafez, B. (2000): Reproduction in farm animals. $7^{\text {th }}$ ed. Philadelphia pp. 192 217.

King, S.S.; Jones, K.L.; Nequin, L.G.; Murphy, L.L. and Campbell, A.G. (2002): Evidence for a local dopamine driven regulatory system in the mare. Theriogenology, 58: 619-622.

Koskinen E.; Huhtinen M. and Katila T. (1996): Serum progesterone levels in mares in winter and during transitional periods. Acta Vet., 37: 409-14.

Nagy, P.; Guillaume, D. and Daels, P. (2000): Seasonality in mares. Anim. Reprod. Sci., 60, 61: 245-62.

Nequin, L.G.; King, S.S.; Roser, J.F. and Soderstrom, B.L. (2000): Uncoupling of the Equine reproductive axes during transition into anoestrus. Journal of reproduction and fertility, Supplement, 56: 153-161.

Nie, G. (2007): Clinical aspects of seasonality in mares. In: Large animal Theriogenology (2): 68-73. Saunders Company $2^{\text {nd }}$ ed.

Nunes, M.M.; Gastal, E.L.; Gastal, M.O.; Rocha Filho, A.N.; Mellagi, A.P. and Ginther, O.J. (2005): Follicle and gonadotropin relationships during the beginning of the anovulatory season in mares. Animal Reproduction, 2: 41-49.

Palmer, E. and Guillaume, D. (1992): Photoperiodism in the equine species: what is a long night? Anim. Reprod. Sci., 28: 21-30.

Parvizi, N. (2000): Neuroendocrine regulation of gonadotropins in the male and female. Animal Reprod. Sci., 60, 61: $31-47$

Saltiel, A.; Calderón, A.; García, N. and Hurley, D.P. (1982): Ovarian activity in the mare between latitude $15^{\circ}$ and $22^{\circ}$ N. J. Reprod. Fert., 32(Suppl.): 261-7.

Salué, K. and Gardon, J.C. (2013): A review of the estrus cycle and neuroendocrine mechanisms in the mare. Steroids and hormonal Science, 4: 115

Sharon, L. and Crowell-Davis (2007): Sexual behavior in mares. Science Direct, Hormones and behavior $52,12-17$.

Squires, E.L.; McKinnon, A.O. and Shideler, R.K. (1988): Use of ultrasound in reproductive management of mares. Theriogenology, 29: 55-70.

Williams, G.L.; Thorson, J.F.; Prezotto, L.D.; Velez, I.C. and Cardoso, R.C. (2012): Reproductive seasonality in the mare: neuroendocrine basis and Pharmacologic control. Domestic Animal Endocrinology, 43: 103-115.

Zimri Cortés-Vidauri; Carlos Aréchiga-Flores; Melba Rincón-Delgado; Fabiola RochínBerumen; Marco López-Carlos and Gilberto Flores-Flores (2018): Mare Reproductive Cycle. Literature review, 8 (3): 14-41. 
الخصائص الفوق صوتية لمبيض الأفراس في المواسم المختلفة في مصر

عماد محمود عبل الرازق ، حماده ضاحي محبوب

E-mail: hamada11eg@yahoo.co.uk Assiut University web-site: www.aun.edu.eg

أجريت هذه الدراسة للكثف عن أنثطة المبيض فى الأفراس باستخدام الموجات فوق الصوتية فيما يتعلق بمو اسم السنة المختلفة في

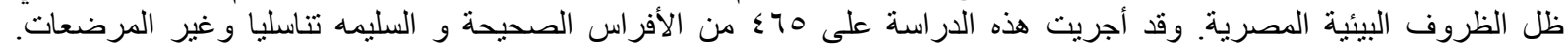

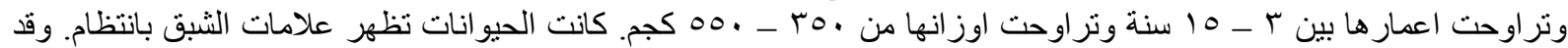

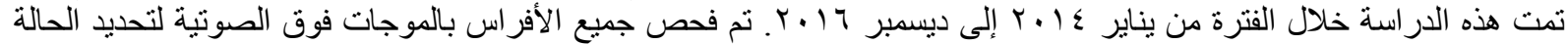

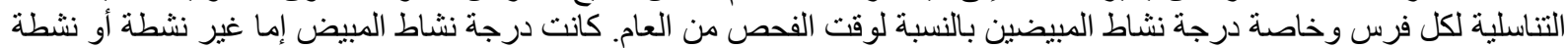

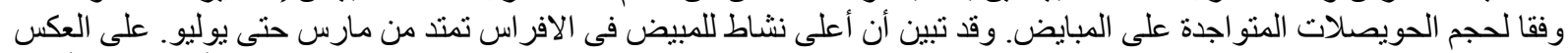

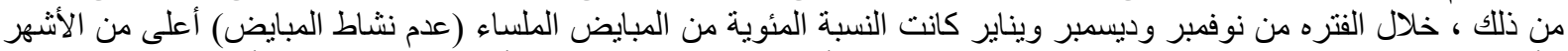

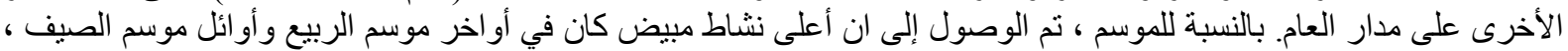

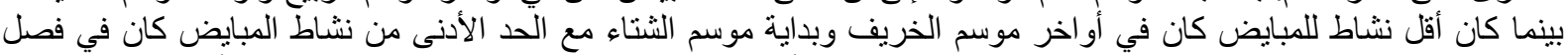

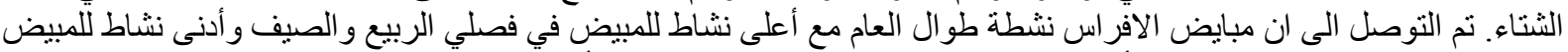

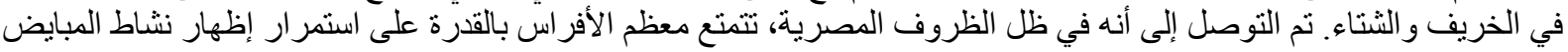

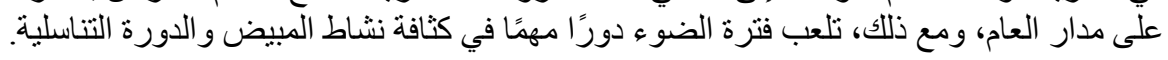

